\title{
Impelementasi Pendekatan Pembelajaran Problem Posing dan Pengaruhnya Terhadap Hasil Belajar Matematika
}

\author{
Kadir \\ Jurusan Pendidikan Matematika, FITK UIN Jakarta \\ E-mail: dirsal@yahoo.com
}

\begin{abstract}
Abstrak: Tujuan penelitian ini dimaksudkan untuk mempelajari pengaruh pembelajaran dengan pendekatan problem posing terhadap hasil belajar matematika. Penelitian dilakukan di MTs Negeri 22 Kampus B Munjul Jakarta Timur Tahun Pelajaran 2005/2006 dengan menggunakan metode eksperimen. Sampel penelitian sebanyak 90 siswa kelas VII yang dipilih dengan teknik cluster random sampling. Data dikumpulkan dengan menggunakan tes, selanjutnya dianalisis dengan menggunakan statistik uji-t. Hasil penelitian mengungkapkan pendekatan problem posing berpengaruh nyata terhadap hasil belajar matematika. Pembelajaran matematika dengan pendekatan problem posing mampu membuat siswa aktif dan kreatif, terlihat dari kemampuan siswa mengembangkan masalah matematika sendiri, mengolah dan mengeksplorasi informasi yang ada dan mengajukan masalah matematika yang dapat diselesaikan. Melalui pembelajaran dengan pendekatan problem posing juga dapat meningkatkan aktivitas siswa dalam proses pembelajaran, khususnya dalam berinteraksi dan sharing idea diantara siswa dan guru sehingga kegiatan pembelajaran lebih bermakna dan pemahaman siswa terhadap konsep menjadi lebih baik.
\end{abstract}

Kata kunci: pendekatan problem posing, pendekatan konvensional, pembelajaran, hasil belajar matematika, aritmetika sosial.

\begin{abstract}
The objective of the present study is to find out the effect of implementation of problem posing approach on the students'learning outcome in mathematics. The study was conducted in MTsN 22 Kampus B Munjul Jakarta Timur at academic year 2005/2006. There were $7^{\text {th }}$ grade students as the sample of the study, selected through cluster random sampling. The data were gathered by using a test. Data analysis was done by using $t$-test. The results of the study have revealed that problem posing approach effected the students' learning outcome in mathematics. Learning in mathematics by problem posing approach can make the students be active and creative, it was shown at competences of the students to develop math's problem themselves, manage, and to explore the information for posing the mathematics' problem that is solvable. Through instructional by problem posing approach can also improve the students' activity in teaching and learning, especially interacting and sharing ideas on both the students each other and the teacher, so learning activity is becoming meaningful the students' mastery of the concept.
\end{abstract}

Key words: problem posing approach, conventional, learning, learning outcome in mathematics, social arithmetics

\section{Pendahuluan}

Sumber daya manusia yang berkualitas adalah investasi masa depan. Pendidikan memegang peranan penting untuk penyiapan sumber daya manusia tersebut. Melalui pendidikan dapat diciptakan generasi penerus bangsa yang mandiri, bertanggung jawab serta bermoral. Pendidikan juga merupakan wahana yang dapat membantu meningkatkan taraf hidup masyarakat. Dengan pendidikan, manusia dapat mengembangkan potensi baik intelektual, fisik, emosional, mental, sosial, ahlak dan etika melalui pendidikan.
Matematika sebagai salah satu pelajaran pokok pada satuan pendidikan memegang peranan yang sangat penting dalam kelangsungan pendidikan peserta didik, karena matematika merupakan metode berfikir logis, kritis, kreatif, keteraturan, seni, dan bahasa yang tidak hanya membantu penelitian di bidang ilmu dan teknologi tetapi juga untuk pembentukan keuletan, kepribadian dan karakter peserta didik. Dalam konteks ini maka setiap jenjang pendidikan, matematika menjadi salah satu mata pelajaran pokok yang wajib diikuti dan dipelajari oleh setiap peserta didik. 
Mengingat akan manfaat matematika tersebut, maka peserta didik pada tingkat pendidikan dasar dan menengah dituntut untuk menguasai matematika dengan baik. Untuk itu, diperlukan usaha tertentu untuk mempelajari dan menguasai matematika dalam segala bentuk kegiatan belajar. Dalam hal ini peranan guru sangatlah penting terutama dalam proses pembelajaran. Guru sebagai tenaga pengajar yang secara langsung melaksanakan proses pendidikan, maka guru harus dapat memotivasi peserta didik untuk berpartisipasi aktif dalam proses pembelajaran.

Untuk menanamkan pemahaman akan konsep matematika diperlukan suatu pendekatan pembelajaran yang tepat dalam menyampaikannya kepada peserta didik. Dalam proses pembelajaran penggunaan pendekatan yang tepat merupakan faktor yang utama dan sangat berpengaruh terhadap peningkatan hasil belajar siswa.

Proses pembelajaran matematika yang bermakna hanya akan terjadi jika proses belajar matematika di kelas berhasil membelajarkan siswa, baik dalam berpikir maupun dalam bersikap. Karena belajar bukan hanya menyerap informasi secara pasif, melainkan aktif menciptakan pengetahuan dan keterampilan. Salah satu alternatif belajar yang dapat digunakan oleh guru untuk mengatasi kepasifan peserta didik pasif adalah dengan menggunakan pendekatan problem posing yang merupakan perumusan masalah matematika oleh siswa dari situasi yang tersedia. Menurut asosiasi guru-guru matematika di Amerika Serikat, yaitu National Council of Teachears of Mathematics (NCTM), problem posing (membuat soal) merupakan "The Heart of Doing Mathematics", yaitu inti dari matematika. Oleh karena itu, NCTM merekomendasikan agar para siswa diberi kesempatan yang sebesar-besarnya untuk mengalami membuat soal sendiri (NTCM, 1989).

Dengan pengajaran problem posing ini dapat memberi rangsangan belajar yang lebih terarah bagi siswa dalam meningkatkan hasil belajar matematikanya. Untuk mempelajari secara empiris apakah pengajaran dengan menggunakan pendekatan problem posing dapat efektif meningkatkan hasil belajar matematika siswa, diadakan suatu penelitian mengenai penggunaan pendekatan problem posing dalam pembelajaran matematika.
Berdasarkan masalah yang ada, maka masalah yang diteliti dibatasi hanya pada pengaruh pendekatan problem posing terhadap hasil belajar matematika siswa. Agar dalam penelitian ini tidak menimbulkan penafsiran yang berbeda-beda, maka diberikan batasan-batasan ruang lingkup masalah sebagai berikut: 1) Hasil belajar yang dimaksud adalah hasil belajar matematika yang diperoleh dari hasil tes instrumen penelitian yang dibuat oleh penulis setelah siswa diberikan pembelajaran menggunakan pendekatan problem posing; 2) Pembelajaran yang dilakukan adalah pembelajaran yang menggunakan pendekatan problem posing yaitu dengan memberikan tugas kepada siswa untuk dapat membuat soal matematika sendiri pada pokok bahasan aritmetika sosial Kelas VII; 3) Pengaruh pendekatan problem posing dapat dilihat dari perbedaan rata-rata hasil belajar matematika siswa antara siswa yang diajar menggunakan pendekatan problem posing dengan hasil belajar matematika siswa yang diajar menggunakan pendekatan konvensional.

Berdasarkan pembatasan masalah diatas, maka masalah pada penelitian ini dirumuskan sebagai berikut: 1) Bagaimana aktivitas dalam pembelajaran matematika dengan pendekatan problem posing? dan 2) Apakah terdapat pengaruh pendekatan problem posing terhadap hasil belajar matematika siswa pada pokok bahasan aritmetika sosial?

Tujuan penelitian ini dimaksudkan untuk mempelajari pengaruh pembelajaran dengan pendekatan problem posing terhadap hasil belajar matematika. Penelitian dilakukan di MTs Negeri 22 Kampus B Munjul Jakarta Timur Tahun Pelajaran 2005/2006.

\section{Kajian Literatur \\ Pengertian Hasil Belajar Matematika}

Belajar adalah kegiatan yang berproses dan merupakan unsur yang sangat fundamental dalam setiap jenis penyelenggaraan dan jenjang pendidikan (Syah, 2004: 89). Belajar bukan semata-mata mengumpulkan atau menghafalkan fakta-fakta yang tersaji dalam bentuk informasi/ materi pelajaran. Menurut pendapat Kimble dan Garmezi dalam (Nana Sudjana, 1989: 5) menyatakan bahwa belajar adalah proses perubahan 
tingkah laku seseorang yang bersifat permanen yang terjadi sebagai hasil dari pengalaman. Sedangkan menurut Writig dalam (Syah, 2004: 64) dalam bukunya "Psychology of learning" mendefinisikan belajar sebagai: "any relatively permanent change in an organism's behavioral repertaire that occurs as a result of experience", artinya belajar adalah perubahan yang relatif menetap yang terjadi dalam segala macam/ keseluruhan tingkah laku suatu organisme sebagai hasil pengalaman.

Dari berbagai pendapat mengenai pengertian belajar diatas dapat disimpulkan bahwa belajar adalah suatu tahapan tingkah laku yang relatif menetap sebagai hasil dari pengalaman, latihan dan interaksi dengan lingkungan yang melibatkan proses kognitif.

Menurut Hudojo di dalam belajar terdapat tiga masalah pokok, salah satunya mengenai bagaimana belajar itu berlangsung dan prinsip mana yang akan dilaksanakan (Hudojo, 1989: 1). Prinsip-prinsip belajar tersebut harus dipilih sesuai dengan disiplin ilmu tertentu. Dalam mempelajari matematika, prinsip-prinsip belajar harus dipilih sesuai dengan disiplin ilmu tertentu karena matematika merupakan disiplin ilmu yang khas dibandingkan dengan disiplin ilmu yang lain. Matematika timbul karena fikiran-fikiran manusia, yang berhubungan dengan idea, proses dan penalaran. Selain itu matematika adalah ratunya ilmu (Mathematics is the queen of the sciences), maksudnya ialah bahwa matematika dapat berdiri sendiri itu tidak bergantung kepada bidang lain tetapi dapat berfungsi untuk bidang lain. Karena itu menurut Ruseffendi (1980: 148) bahwa agar dapat dipahami orang dengan tepat kita harus menggunakan simbol dan istilah yang cermat yang disepakati secara bersama.

Matematika bukan saja menyampaikan informasi secara jelas dan tepat namun juga singkat. Selanjutnya menurut Johnson dan Rising dalam (Suherman dan Udin S Winataputra, 1992: 102), mengemukakan bahwa matematika adalah pola berpikir, pola mengorganisasikan, pembuktian yang logis, matematika itu adalah bahasa yang menggunakan istilah yang didefinisikan dengan cermat, jelas dan akurat, representasinya dengan simbol dan padat, lebih serupa bahasa simbol mengenai ide daripada bunyi.
Ide-ide dalam matematika tersusun secara hirarkis. Oleh karena itu, belajar matematika yang terputus-putus dapat menyebabkan terganggunya proses belajar matematika. Dalam mempelajari matematika, ada dua obyek yang dapat diperoleh siswa yaitu obyek langsung dan obyek tak langsung. Obyek langsung dalam matematika adalah fakta, konsep, prinsip dan keterampilan. Sedangkan obyek tak langsung dalam belajar matematika adalah disiplin diri, kemampuan memecahkan soal serta bersikap positif terhadap matematika.

Belajar matematika itu sendiri merupakan kegiatan mental yang tinggi. Oleh karena itu, dalam mempelajarinya harus bertahap dan berurutan serta mendasarkan kepada pengalaman yang sudah diperoleh. Siswa yang benar-benar belajar dalam dirinya akan terjadi perubahan tingkah laku yang diperlihatkan dalam bentuk hasil belajar. Hasil belajar atau achievement merupakan realisasi atau pemekaran dari kecakapan-kecakapan potensial atau kapasitas yang dimiliki seseorang. Penguasaan hasil belajar oleh seseorang dapat dilihat dari perilakunya baik perilaku dalam bentuk penguasaan pengetahuan dan keterampilan berpikir (Sukmadinata, 2003: 102-103).

Untuk menguasai matematika, siswa harus mampu memahami konsep-konsep dan berupaya menerapkannya dalam menyelesaikan masalah dan dalam kehidupan sehari-hari. Untuk menilai hasil belajar matematika yang telah dicapai siswa dalam proses belajar mengajar, perlu dilakukan suatu kegiatan evaluasi. Evaluasi dalam proses belajar mengajar sungguh sangat penting, karena dengan evaluasi akan diketahui apakah proses belajar mengajar tersebut telah mencapai tujuan atau belum.

Hasil belajar matematika yang diperoleh siswa dapat dilihat dan diukur dengan menggunakan alat evaluasi berupa tes. Seperti halnya pada kecerdasan dan bakat, hasil belajar dapat diukur dengan tes hasil belajar atau tes prestasi belajar (achievement test). Tes hasil belajar, adalah instrumen yang digunakan untuk mengukur variabel hasil belajar matematika setelah peserta didik mengikuti proses pembelajaran. Dengan demikian, efektifitas proses pembelajaran yang telah diberikan selama kurung waktu tertentu di- 
ukur dengan instrumen tersebut. Dari pengertianpengertian di atas dapat disumpulkan bahwa hasil belajar matematika adalah penguasaan kompetensi aritmetika sosial setelah siswa mengikuti proses pembelajaran pada materi Aljabar dan Aritmetika Sosial.

\section{Pendekatan Problem Posing}

Dalam pembelajaran matematika terdapat beberapa pendekatan pembelajaran, salah satu cara untuk mengembangkan pembelajaran matematika adalah dengan pendekatan problem posing. Pengertian Problem posing adalah perumusan masalah matematika oleh siswa dari situasi yang tersedia, baik dilakukan sebelum, ketika, atau setelah pemecahan masalah tersebut (Gita, 1999: 23).

Beberapa istilah yang digunakan sebagai padanan istilah problem posing seperti pengajuan masalah, pengajuan soal, pembentukan soal, pengkontruksian soal dan pertanyaan yang dihasilkan siswa (Suharta, 2001: 2). Selanjutnya Silver dan Cai (1996b: 294- 309) mengemukakan bahwa istilah problem posing digunakan untuk merujuk kepada dua pengertian, yaitu: 1) mengembangkan masalah baru dan 2) merumuskan kembali masalah yang diberikan. Selanjutnya Suryanto (1998) menggunakan istilah "pembentukan soal" sebagai padanan istilah problem posing. Kata "soal" dapat juga diartikan sebagai "problem" atau "masalah".

Silver dan Cai (1996b: 292), mengemukakan bahwa dalam pustaka pendidikan matematika problem posing mempunyai tiga pengertian. Pertama, problem posing ialah perumusan masalah/soal sederhana atau perumusan ulang masalah yang ada dengan beberapa cara dalam rangka menyelesaikan masalah yang rumit sehingga dapat diselesaikan. Pengertian ini merupakan salah satu langkah dalam menyusun rencana pemecahan masalah. Kedua, problem posing ialah perumusan masalah yang berkaitan dengan syarat-syarat pada soal yang telah dipecahkan, dalam rangka pencarian alternatif pemecahan yang masih relevan. Arti kedua ini berkaitan dengan langkah-langkah mengkaji ulang dalam tahap-tahap penyelesaian yang dianjurkan Polya. Ketiga, problem posing ialah merumuskan atau mengajukan masalah/soal dari situasi yang tersedia, baik dilakukan sebelum, selama, atau setelah penyelesaian suatu masalah.

Sehubungan dengan pengertian problem posing, baik dilakukan sebelum, selama, atau setelah pemecahan masalah, Silver \& Cai (1996b: 521) menyatakan bahwa istilah problem posing umumnya digunakan pada tiga bentuk kegiatan kognitif matematis, yaitu: 1) sebelum pengajuan solusi, yaitu satu pengembangan masalah awal dari suatu situasi stimulus yang diberikan; 2) di dalam pengajuan solusi, yaitu merumuskan kembali masalah agar menjadi mudah untuk diselesaikan; dan 3) setelah pengajuan solusi, yaitu memodifikasi tujuan atau kondisi dari masalah yang sudah diselesaikan untuk merumuskan masalah baru. Bentuk pertama inilah yang akan dilakukan dalam penelitian ini. Dengan pertimbangan bahwa bentuk kedua dan ketiga lebih merupakan bagian dari problem solving dari pada problem posing.

Berdasarkan pengertian yang telah dikemukakan di atas, disimpulkan bahwa yang dimaksud dengan problem posing adalah pengajuan masalah atau merumuskan soal terhadap situasi atau tugas yang diberikan, baik sebelum, selama atau setelah penyelesaian masalah. Istilah "merumuskan masalah dapat juga diartikan sebagai "merumuskan pertanyaan". Istilah yang penulis gunakan ini lebih merujuk kepada istilah yang digunakan dalam Curriculum and Evaluation Standards for School Mathematics yang menyatakan "Investigation and formulating questions from problem situation" (NCTM, 1989: 70).

Pengajuan masalah adalah suatu bentuk pendekatan dalam pembelajaran matematika yang menekankan pada perumusan masalah atau soal. Pendekatan ini merupakan salah satu alternatif pembelajaran yang dapat mengembangkan kemampuan berfikir kreatif dan bernalar matematis.

Brown dan Walter (1990), menyatakan bahwa problem posing dalam pembelajaran matematika memiliki dua tahap kognitif, yaitu accepting (menerima) dan challenging (menantang). Tahap menerima adalah suatu kegiatan dimana siswa menerima tugas atau masalah yang telah ditentukan. Sedangkan tahap menantang adalah suatu kegiatan dimana siswa menantang tugas 
yang diberikan dalam rangka perumusan masalah.

Dengan demikian, yang dimaksud dengan pendekatan problem posing dalam penelitian ini adalah pendekatan yang menekankan pada perumusan atau pengajuan masalah oleh siswa dari situasi atau tugas yang tersedia. Sedangkan pengertian masalah dalam penelitian ini adalah soal atau pertanyaan. Dengan membuat atau mengkonstruksi soal atau masalah yang dapat diselesaikan, siswa senantiasa mengkonstruksi pemahaman baru berdasarkan informasi yang tersedia. Pertanyaan-pertanyaan yang dimunculkan seringkali menjadi pemicu terbentuknya pemahaman yang lebih mantap pada diri seseorang. Melalui pendekatan problem posing siswa dapat mengembangkan pola pikir matematika siswa seperti berpikir logis dan kritis. Lebih jauh lagi pengembangan problem posing dalam matematika akan dapat memperbaiki kemampuan pemecahan masalah.

\section{Pendekatan Konvensional}

Pendekatan konvensional yang dimaksud adalah pendekatan secara klasikal, seperti yang biasa kita lihat sehari-hari di setiap sekolah pada umumnya. Dalam pendekatan pembelajaran konvensional ini siswa diasumsikan memiliki minat dan kecepatan belajar yang relatif sama. Proses pembelajaran konvensional ini lebih berpusat kepada guru (Suherman, 2002: 255). Pendekatan konvensional dengan pendekatan yang berpusat pada guru, hampir seluruh kegiatan pembelajaran dikendalikan penuh oleh guru, seluruh rangkaian kegiatan dibawa kendali guru, tanpa ada usaha untuk mencari dan menerapkan strategi belajar yang relevan dengan karakteristik peserta didik.

Dalam pembelajaran konvensional biasanya guru menyampaikan informasi mengenai bahan pelajaran dalam bentuk penjelasan dan penuturan secara lisan, yang dikenal dengan istilah metode ceramah. Pembelajaran ini cenderung membuat siswa pasif dalam belajar, karena komunikasi yang digunakan oleh guru dalam interaksinya dengan siswa adalah komunikasi satu arah. Siswa hanya mendengar-kan, mencatat dan sekali-sekali bertanya mengenai hal-hal apa yang disampaikan oleh guru.

Menurut Nana Sudjana (1989: 40-41), proses pembelajaran dengan pendekatan konvensional pada umumnya sebagai berikut : 1) Siswa duduk, mencatat, mendengar dan menghafal; 2 . Sumber informasi hanya dari guru; 3; Siswa tidak dituntut untuk menemukan konsep; 4. Metode yang digunakan guru adalah metode ceramah; 5 . Suasana kelas membosankan; 6. Kurang, karena guru lebih aktif; 7. Materi pembelajaran banyak dan berat; dan 8) Banyak waktu yang terbuang.

Berdasarkan uraian di atas, pendekatan konvensional merupakan pembelajaran dengan cara penyampaian pelajaran yang dilakukan guru dengan penjelasan lisan secara langsung terhadap siswa. Pendekatan pembelajaran konvensional dapat juga diartikan sebagai pendekatan yang sering digunakan guru di sekolah pada umumnya, sehingga pembelajaran dengan pendekatan konvensional tidak perlu diteliti kembali. Oleh karena itu, kelompok siswa yang diajar dengan menggunakan pendekatan konvensional dapat dijadikan sebagai kelompok kontrol dalam penelitian yang menggunakan pendekatan eksperimental semu yaitu dimana satu kelas diajar dengan menggunakan pendekatan problem posing sementara kelas yang lain diajar dengan menggunakan pendekatan konvensional.

Secara garis besar perbandingan kegiatan pembelajaran antara pendekatan problem posing dan pendekatan konvensional dapat dibedakan pada Tabel 1:

\section{Materi Pembelajaran Aritmetika Sosial}

Pengajaran Aritmetika sosial adalah pengajaran yang membahas mengenai jual beli, untung rugi, perhitungan perdagangan seperti: netto, bruto, tara dan perhitungan persen pada tabungan dan koperasi (Nurdin, 1998: 10). Aritmatika sosial merupakan materi pembelajaran matematika kelas VII semester I. Adapun materi pembelajaran aritmetika sosial adalah sebagai berikut: 1) Harga pembelian, harga penjualan, laba dan rugi; 2) Menghitung nilai keseluruhan, nilai per-unit dan nilai sebagian; 3) Menentukan persentase laba, rugi, harga penjualan dan harga pembelian; 4) Menentukan harga pembelian atau harga penjualan berdasarkan persentase laba atau rugi yang diketahui; 5) Rabat (diskon), bruto, tara, dan netto dan 6) Bunga tabungan dan pajak. 
Tabel 1. Perbandingan Kegiatan Pembelajaran antara Pendekatan Problem Posing dan Pendekatan Konvensional

\begin{tabular}{|c|c|}
\hline $\begin{array}{l}\text { Pembelajaran Dengan Pendekatan } \\
\text { Problem Posing }\end{array}$ & $\begin{array}{l}\text { Pembelajaran Dengan } \\
\text { Pendekatan Konvensional }\end{array}$ \\
\hline $\begin{array}{l}\text { 1. Siswa mendengarkan dan memperhatikan } \\
\text { penjelasan tentang materi pelajaran dari } \\
\text { guru. }\end{array}$ & $\begin{array}{l}\text { 1. Siswa mendengarkan dan memper- } \\
\text { hatikan penjelasan tentang materi } \\
\text { pelajaran dari guru. }\end{array}$ \\
\hline $\begin{array}{l}\text { 2. Siswa memperhatikan penjelasan guru } \\
\text { mengenai bagaimana cara membuat soal } \\
\text { atau masalah dan penyelesaiannya. }\end{array}$ & $\begin{array}{l}\text { 2. Siswa memperhatikan contoh soal dan } \\
\text { penyelesaiannya yang dijelaskan oleh } \\
\text { guru. }\end{array}$ \\
\hline $\begin{array}{l}\text { 3. Siswa menanyakan hal-hal yang di- } \\
\text { rasakan belum jelas. }\end{array}$ & $\begin{array}{l}\text { 3. Siswa menanyakan hal-hal yang } \\
\text { dirasakan belum jelas. }\end{array}$ \\
\hline $\begin{array}{l}\text { 4. Siswa membuat soal sebanyak mungkin } \\
\text { dari situasi masalah yang diberikan guru } \\
\text { dan mempresentasikannya di depan kelas } \\
\text { serta menyelesaikannya. }\end{array}$ & $\begin{array}{l}\text { 4. Siswa mengerjakan latihan soal yang } \\
\text { diberikan guru. (Siswa tidak membuat } \\
\text { soal). }\end{array}$ \\
\hline $\begin{array}{l}\text { 5. Siswa membuat soal atau masalah } \\
\text { kembali kemudian menukarkannya soal } \\
\text { tersebut dengan teman sekelas dan } \\
\text { menyelesaikannya. }\end{array}$ & $\begin{array}{l}\text { 5. Siswa bersama guru membahas latih- } \\
\text { an soal yang dikerjakan oleh siswa. }\end{array}$ \\
\hline
\end{tabular}

\section{Hasil Penelitian Relevan}

Beberapa laporan hasil penelitian yang mengkaitkan pendekatan problem posing dalam pembelajaran matematika, antara lain: Penelitian Silver dan Cai (1996a) tentang analisis pengajuan masalah matematika melibatkan 509 siswa kelas 6 dan kelas 7. Studi ini menemukan bahwa dari 1465 respon yang diajukan oleh responden, terdapat $(70 \%)$ respon berupa masalah matematika, (10\%) pertanyaan non-matematika dan $(20 \%)$ pernyataan. Sekitar $90 \%$ soal matematika yang diajukan responden dapat diselesaikan dan sesuai dengan situasi yang diberikan. Penelitian Silver and Cai (1996a), sehubungan dengan pembelajaran pengajuan masalah matematika, melaporkan bahwa tidak terdapat perbedaan yang signifikan antara jumlah respon yang diajukan responden secara individu dan berpasangaan dari tugas yang diberikan. Tetapi, respon yang diajukan secara individu menunjukkan kualitas yang lebih tinggi. Hal ini diperlihatkan oleh rendahnya hubungan semantik dan struktur sintaksis yang terkandung dalam setiap masalah yang diajukan siswa.

Penelitian serupa yang dilakukan. I Gusti Putu Suharta (2001) tentang upaya peningkatan kemampuan pemecahan masalah matematika melalui mengintegrasian pengajuan Masalah (Problem Posing) pada siswa kelas II SMU 2 Singaraja. Temuan penelitian ini, melaporkan bahwa: Terdapat peningkatan kemampuan pemecahan masalah, namun belum dapat diungkap besar peningkatannya, disamping itu terdapat peningkatan aktivitas setelah pembelajaran dengan pendekatan Problem Posing.

\section{Kerangka Berpikir}

Pembelajaran matematika yang baik hanya akan terjadi jika proses belajar matematika di kelas berhasil membelajarkan siswa baik dalam berpikir maupun dalam bersikap. Proses pembelajaran matematika di kelas yang tidak mampu membelajarkan siswa, tidak akan mampu mengembangkan kemampuan berpikir kritis, logis, cermat, sistematis, kreatif dan inovatif serta sikap percaya diri, pantang menyerah, ulet dan disiplin. Oleh karena itu, proses belajar mengajar harus dirancang sedemikian rupa oleh para guru dan siswa dilibatkan secara aktif, mental dan fisiknya dalam belajar matematika.

Pendekatan problem posing merupakan salah satu strategi pembelajaran yang dapat menuntut siswa untuk aktif, berpikir kritis dan logis dalam belajar matematika. Melalui pendekatan problem 
posing dalam pembelajaran matematika proses kognitif dapat dilibatkan. Soal atau situasi masalah yang diberikan oleh guru, dicandra penginderaan kemudian disimpan dalam bentuk jaringanjaringan informasi dalam short term memory atau long term memory kemudian dianalisis dan diputuskan dengan mengajukan masalah yang sesuai. Karena itu, pendekatan problem posing dalam matematika melibatkan proses kognitif yang kompleks sehingga dapat mengembangkan pola pikir matematika siswa. Selain itu aktivitas problem posing dalam kelas akan dapat menyebabkan diskusi dan sharing ideas tentang matematika antara siswa satu dengan yang lainnya menjadi lebih kondusif.

Berdasarkan rasional di atas, maka pembelajaran matematika dengan pendekatan problem posing mampu membuat siswa untuk aktif dalam belajar, serta dapat mengembangkan dan melatih pola pikir matematika siswa untuk berpikir kritis, logis dan kreatif. Oleh karena itu, dengan pendekatan problem posing ini dapat diduga bahwa hasil belajar matematika siswa yang diberi pendekatan problem posing lebih tinggi dari pendekatan konvensional.

\section{Hipotesis Penelitian}

Berdasarkan kerangka berpikir yang telah diuraikan diatas, maka hipotesis penelitian dapat dirumuskan: "Hasil belajar matematika siswa yang diajar dengan menggunakan pendekatan problem posing lebih tinggi dari hasil belajar matematika siswa yang diajar dengan menggunakan pendekatan konvensional"

\section{Metodologi Penelitian \\ Tempat dan Waktu Penelitian}

Penelitian ini dilakukan di MTs Negeri 22 Kampus B Munjul Jakarta Timur. Penelitian dimulai dari bulan September sampai dengan bulan November semester I Tahun Pelajaran 2005/2006.

\section{Populasi dan Sampel}

Populasi terjangkau dalam penelitian ini adalah seluruh siswa MTs Negeri 22 Kampus B Munjul Jakarta Timur Tahun Pelajaran 2005/2006, sedangkan populasi sasaran yaitu seluruh siswa kelas VII MTs Negeri 22 Kampus B Munjul Jakarta Timur sebanyak 187 siswa yang tersebat di kelas
VII-A (47 siswa), VII-B (46 siswa), VII-C (46 siswa), VII-D (47 siswa. Sampel penelitian diambil dari populasi terjangkau, yaitu dari 4 kelas VII yang ada di MTs Negeri 22 Kampus B Jakarta Timur. Selanjutkan dengan teknik cluster random sampling, dari 4 kelas VII tersebut diambil secara acak dua kelas dan terpilih kelas VII-A dan VII-D sebagai kelompok perlakuan pembelajaran. Penentuan kelas eksperimen yaitu kelas dimana siswa diajar dengan menggunakan pendekatan problem posing dan kelas kontrol yaitu kelas dimana siswa diajar dengan menggunakan pendekatan konvensional dilakukan dengan teknik random penempatan. Selanjutnya dari kelas eksperimen dan kelas kontrol diambil masingmasing 30 siswa secara acak.

\section{Metode dan Desain Penelitian}

Metode penelitian yang digunakan dalam penelitian ini adalah metode quasi eksperimen. Sedangkan rancangan atau desain penelitian yang digunakan untuk menerapkan perlakuan pembelajaran adalah Randomized Control Group Design. Rancangan penelitian dinyatakan sebagai berikut.

Tabel 2. Rancangan Penelitian

\begin{tabular}{|c|c|c|}
\hline Kelompok & Variabel Bebas & Tes Akhir \\
\hline$(\mathrm{R}) \mathrm{E}$ & $\mathrm{XE}$ & $\mathrm{Y}$ \\
\hline$(\mathrm{R}) \mathrm{K}$ & $\mathrm{XK}$ & $\mathrm{Y}$ \\
\hline
\end{tabular}

Keterangan:

$\mathrm{R}$ : Pemilihan secara acak kelas

E : Kelompok eksperimen dengan pendekatan problem posing.

$\mathrm{K}$ : Kelompok kontrol dengan pendekatan konvensional.

$X_{E}$ : Perlakuan yang diberikan pada kelompok eksperimen.

$\mathrm{X}_{\mathrm{K}}$ : Perlakuan yang diberikan pada kelompok kontrol.

Y : Tes akhir

\section{Instrumen}

Hasil belajar matematika dijaring melalui tes hasil belajar pokok aritmetika sosial setelah perlakuan pembelajaran dengan pendekatan problem posing dan pendekatan konvesional. Instrumen yang digunakan untuk mengukur hasil belajar matematika siswa adalah tes obyektif dalam bentuk pilihan ganda dengan 4 pilihan yang terdiri dari 40 butir 
soal yang meliputi pokok bahasan aritmetika sosial. Penentukan validitas butir (kriteria) dilakukan dengan menggunakan rumus koefisien point Biserial. Hasil perhitungan berdasarkan hasil uji-coba instrumen terhadap 40 butir soal, diperoleh 25 butir yang dinyatakan valid dan 15 butir yang tidak valid. Koefisien point Biserial sebagai ukuran validitas butir soal berkisar $(0,362$ - 0,653). Selanjutnya dari butir soal yang valid tersebut dihitung koefisien reliabilitasnya dengan menggunakan rumus Kuder-Richardson (KR-20). Dari hasil perhitungan koefisien reliabilitas instrumen hasil belajar matematika diperoleh koefisien sebesar 0,83 atau tergolong tinggi. Dengan demikian, instrumen hasil belajar matematika yang digunakan dalam penelitian ini memadai untuk digunakan sebagai alat untuk menjaring data hasil belajar matematika khususnya hasil belajar Aritmetika Sosial.

\section{Teknik Analisis Data}

Teknik analisis yang digunakan dalam penelitian ini meliputi teknik analisis deskriptif dan teknik analisis inferensial. Teknik analisis deskriptif digunakan untuk memperoleh gambaran tentang ukuran kecenderungan memusat dan menyebarnya data meliputi rata-rata, median, modus, rentang, standar deviasi, varians, dan kemiringan. Sedangkan teknik analisis inferensial digunakan untuk membuat kesimpulan berdasarkan hasil pengujian hipotesis. Teknik analisis inferensial yang digunakan dalam penelitian ini adalah teknik analisis statistik uji - $\mathrm{t}$ dengan taraf signifikan $\mathrm{a}=$ 0,05 .

Sebelum dilakukan pengujian hipotesis terlebih dahulu dilakukan pengujian normalitas dan kesamaan varians (uji homogenitas). Pengujian normalitas dilakukan dengan menggunakan uji Lilliefors. Sedangkan uji homogenitas dilakukan dengan uji Fisher. Setelah memenuhi kedua persyaratan ini, selanjutnya pengujian hipotesis statistik dilakukan. Adapun rumusan hipotesis statistik yang akan diuji adalah.

$$
\begin{aligned}
& H_{0}: \mu_{1} \leq \mu_{2} \\
& H_{1}: \mu_{1}>\mu_{2}
\end{aligned}
$$

\section{Hasil Penelitian dan Pembahasan Hasil belajar matematika siswa yang diajar dengan pendekatan problem posing}

Berdasarkan data hasil belajar matematika pada materi aritmetika sosial kelompok siswa yang diajar menggunakan pendekatan problem posing diperoleh rentangan nilai dari 40 sampai dengan 96 dengan nilai rata-rata sebesar 71,20, modus 69,50 , median 72,36, varians sebesar 225,54 dan standar deviasi sebesar 15,02. Hasil analisis deskriptif disajikan pada tabel distribusi frekuensi berikut.

Tabel 3. Distribusi Frekuensi Hasil Belajar

\begin{tabular}{|c|c|c|c|c|c|}
\hline No & Nilai & $\begin{array}{c}\text { Titik } \\
\text { Tengah }\end{array}$ & $\begin{array}{c}\text { Freku } \\
\text { ensi } \\
\text { Abso } \\
\text { lut }\end{array}$ & $\begin{array}{c}\text { Freku } \\
\text { ensi } \\
\text { Kumu } \\
\text { latif }\end{array}$ & $\begin{array}{c}\text { Freku } \\
\text { ensi } \\
\text { Rela } \\
\text { tif(\%) }\end{array}$ \\
\hline 1 & $40-49$ & 44,5 & 3 & 3 & 10 \\
\hline 2 & $50-59$ & 54,5 & 3 & 6 & 10 \\
\hline 3 & $60-69$ & 64,5 & 7 & 13 & 23,33 \\
\hline 4 & $70-79$ & 74,5 & 7 & 20 & 23,33 \\
\hline 5 & $80-89$ & 84,5 & 6 & 26 & 20 \\
\hline 6 & $90-99$ & 94,5 & 4 & 30 & 13,33 \\
\hline \multicolumn{2}{|c|}{ Jumlah } & - & 30 & - & 100 \\
\hline
\end{tabular}
Matematika Siswa Kelompok Eksperimen

Secara visual deskripsi data hasil belajar matematika kelompok eksperimen disajikan pada Histogram dan Poligon Frekuensi berikut ini.

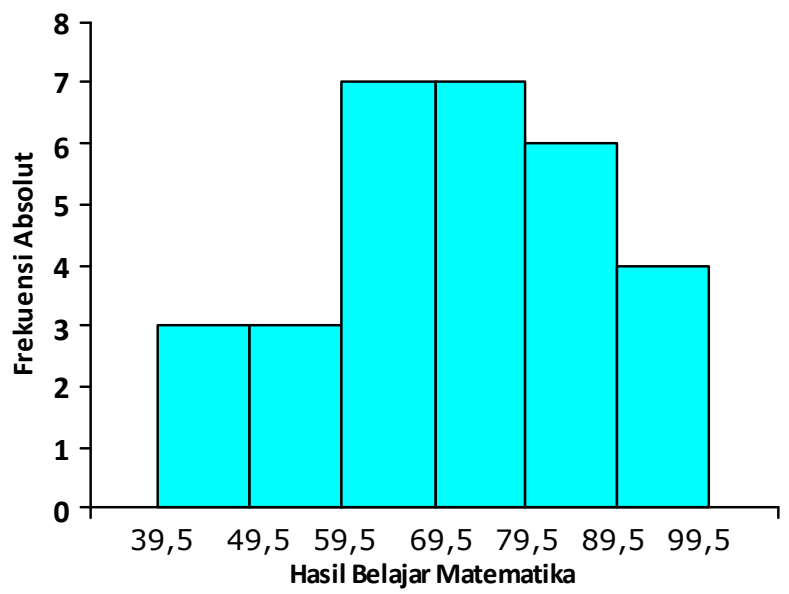

Gambar 1 : Histogram Hasil Belajar Matematika Siswa dengan Pendekatan Problem Posing 
Dari gambar di atas dapat dilihat bahwa frekuensi absolut tertinggi berada pada rentang 59,5 - 69,5 dan rentang 69,5 - 79,5, frekuensi absolut terendah berada pada rentang $39,5-49,5$ dan rentang 49,5 - 59,5 dan median data terletak pada rentang 69,5 - 79,5. Gambar histogram dan poligon di atas memiliki kemiringan sebesar $-0,113$ atau memiliki kemiringan yang negatif. Dengan demikian, data hasil belajar matematika siswa yang diberi pendekatan problem posing memiliki kecendrungan mengelompok di atas rata-rata empirik.

\section{Hasil belajar matematika siswa yang diajar dengan pendekatan konvensional}

Berdasarkan hasil analisis deskriptif data hasil belajar matematika siswa yang diajar dengan pendekatan konvensional: diperoleh rentangan nilai dari 32 sampai dengan 84 dengan nilai ratarata sebesar 61,60 , modus 69,75 , median 63,64 , varians sebesar 166,18 dan standar deviasi sebesar. Rangkuman hasil analisis data hasil belajar matematika kelompok kontrol disajikan pada tabel berikut.

Dari tabel 4. dapat dilihat bahwa frekuensi absolut tertinggi berada pada rentang 67,5 76,5 , frekuensi absolut terendah berada pada rentang 31,5 - 40,5 dan median data terletak pada rentang $58,5-67,5$.

Secara visual deskripsi data hasil belajar matematika kelompok kontrol disajikan pada Histogram dan Poligon Frekuensi berikut ini.

Tabel 4. Distribusi Frekuensi Hasil Belajar Matematika Siswa Kelompok Kontrol

\begin{tabular}{|l|c|c|c|c|c|}
\hline No & Nilai & $\begin{array}{c}\text { Titik } \\
\text { Tengah }\end{array}$ & $\begin{array}{c}\text { Freku } \\
\text { ensi } \\
\text { Abso } \\
\text { lut }\end{array}$ & $\begin{array}{c}\text { Freku } \\
\text { ensi } \\
\text { Kumu } \\
\text { latif }\end{array}$ & $\begin{array}{c}\text { Freku } \\
\text { ensi } \\
\text { Rela } \\
\text { tif(\%) }\end{array}$ \\
\hline 1 & $32-40$ & 36 & 2 & 2 & 6,67 \\
2 & $41-49$ & 45 & 3 & 5 & 10 \\
3 & $50-58$ & 54 & 6 & 11 & 20 \\
4 & $59-67$ & 63 & 7 & 18 & 23,33 \\
5 & $68-76$ & 72 & 9 & 27 & 30 \\
6 & $77-85$ & 81 & 3 & 30 & 10 \\
\hline \multicolumn{2}{|l}{ Jumlah } & 30 & - & 100 \\
\hline
\end{tabular}

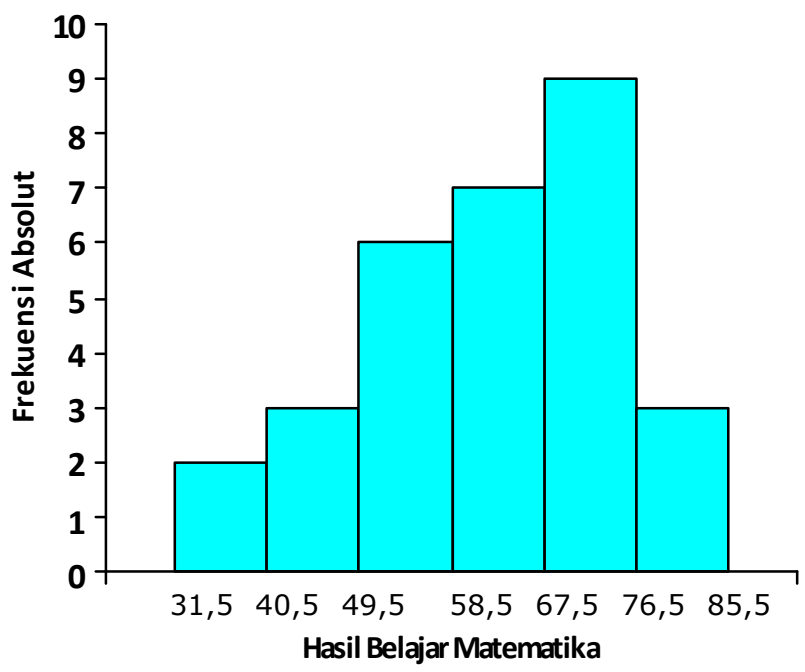

Gambar 2. Histogram Hasil Belajar Matematika Siswa yang diajar dengan Pendekatan Konvensional

Gambar histogram dan poligon di atas memiliki koefisien kemiringan sebesar - 0,632 atau memiliki kemiringan yang negatif. Dengan demikian, data hasil belajar matematika siswa yang diberi pendekatan konvensional sedikit memiliki kecendrungan mengelompok di atas rata-rata empirik.

\section{Perbandingan Hasil Belajar Matematika Antara Kelompok Eksperimen dan Kelompok Kontrol}

Secara garis besar perbandingan hasil belajar matematika antara kelompok eksperimen dan kelompok kontrol ditunjukkan pada tabel berikut.

Tabel 5. Perbandingan Hasil Belajar Matematika Kelompok Eksperimen Dan Kelompok Kontrol

\begin{tabular}{|l|c|c|}
\hline Statistik & $\begin{array}{c}\text { Kelompok } \\
\text { Eksperimen }\end{array}$ & $\begin{array}{c}\text { Kelompok } \\
\text { Kontrol }\end{array}$ \\
\hline $\mathrm{n}$ & 30 & 30 \\
Rata-rata & 71,20 & 61,60 \\
Modus & 69,50 & 69,75 \\
Median & 72,36 & 63,64 \\
Varians & 225,54 & 166,18 \\
Standar Deviasi & 15,02 & 12,89 \\
Kemiringan & $-0,113$ & $-0,632$ \\
\hline
\end{tabular}

\section{Pengujian Persyaratan analisis}

Sebelum dilakukan pengujian hipotesis, terlebih dahulu akan dilakukan pengujian persyaratan 
analisis, meliputi uji normalitas dan homogenitas. Pengujian normalitas dilakukan dengan menggunakan Uji Liliefors. Hasil pengujian normalitas data kelompok eksperimen dan kontrol disajikan pada tabel berikut.

Tabel 6. Hasil Pengujian Normalitas

\begin{tabular}{|l|c|c|c|c|}
\hline Kelompok & $\begin{array}{c}\text { Sampel } \\
(\mathrm{n})\end{array}$ & $L_{\text {hitung }}$ & $L_{\text {tabel }}$ & $\begin{array}{c}\text { Kesim- } \\
\text { pulan }\end{array}$ \\
\hline Ekperimen & 30 & 0,051 & 0,161 & Normal \\
Kontrol & 30 & 0,081 & 0,161 & Normal \\
\hline
\end{tabular}

Dari hasil pengujian normalitas pada taraf signifikan $\alpha=0,05$, baik kelompok eksperimen dan kontrol, diperoleh $L_{\text {hitung }} \leq L_{\text {tabel }}$. Hal ini berarti bahwa data hasil belajar matematika siswa kelompok eksperimen maupuan kelompok kontrol berasal dari populasi berdistribusi normal.

Uji homogenitas atau uji kesamaan dua variabel (varians) populasi kedua kelompok dilakukan dengan menggunakan Uji Fisher. Dari hasil pengujian diperoleh nilai $F_{\text {hitung }}=1,357$ sedangkan dari daftar distribusi $F$ pada taraf signifikan $\alpha=0,05$ dengan derajat kebebasan pembilang 29 dan derajat kebebasan penyebut 29 diperoleh $F_{\text {tabel }}=1,864$. Karena $F_{\text {hitung }} \leq F_{\text {tabel }}$ yaitu $1,357 \leq 1,864$ maka diterima pada $\alpha=0,05$ yang berarti bahwa data dari kedua kelompok penelitian mempunyai varians yang sama atau data dari kedua kelompok tersebut adalah homogen.

\section{Pengujian Hipotesis}

Setelah dilakukan pengujian persyaratan analisis, selanjutnya dilakukan pengujian hipotesis dengan menggunakan statistik uji - t. Hasil pengujian hipotesis disajikan pada tabel berikut.

Tabel 7. Hasil Pengujian Hipotesis

Dari hasil analisis yang disajikan pada tabel di atas, diperoleh $t_{\text {hitung }}>t_{\text {tabel }}$ maka, ditolak dan $H_{1}$ ditolak. Hal ini berarti hasil belajar matematika siswa yang diajar dengan menggunakan pendekatan problem posing lebih tinggi dibandingkan dengan hasil belajar matematika siswa yang diajar dengan menggunakan pendekatan konvensional.

\section{Pembahasan Hasil Penelitian}

Berdasarkan deskripsi data temuan dan pengujian hipotesis, menunjukkan bahwa hasil belajar siswa yang diajar dengan pendekatan problem posing ternyata lebih tinggi daripada hasil belajar siswa yang diajar dengan pendekatan konvensional. Perbedaan hasil belajar ini, terlihat dari skor ratarata hasil belajar yang diperoleh siswa dengan pendekatan problem posing lebih tinggi dibandingkan skor rata-rata hasil belajar siswa yang diajar dengan cara pendekatan konvensional.

Ditinjau dari tingkat/taraf keberhasilan belajar mengajar, suatu kegiatan pembelajaran akan memiliki tingkat efektivitas yang sangat baik jika dapat mencapai minimal $60 \%$ dari tujuan pembelajaran yang telah direncanakan. Ternyata pembelajaran dengan pendekatan problem posing mencapai $80 \%$ mendapatkan nilai diatas cukup (24 orang mendapat nilai 60 ). Ini berarti tujuan pembelajaran yang telah direncanakan dapat dicapai dengan baik dan optimal. Hal ini menunjukkan pula bahwa pembelajaran dengan pendekatan problem posing memberikan harapan yang lebih baik dalam pelaksanaan pendidikan matematika. Temuan penelitian serupa dengan temuan penelitian Penelitian serupa yang dilakukan, I Gusti Putu Suharta (2001) pada siswa kelas II SMU 2 Singaraja yang melaporkan bahwa: Terdapat peningkatan kemampuan pemecahan masalah, namun belum dapat diungkap besar peningkatannya, disamping itu terdapat peningkatan aktivitas setelah pembelajaran dengan pendekatan Problem Posing.

Berdasarkan analisis kemampuan siswa merespon situasi masalah atau membuat soal berdasarkan tugas-tugas berisi masalah, tampak bahwa siswa yang diajar dengan pendekatan problem posing mengalami proses belajar yang positif, dimana semua siswa terpacu untuk terlibat secara aktif dalam kegiatan perumusan soal. Dengan pendekatan problem posing siswa lebih antusias/berkonsentrasi dalam mengikuti pela- 
jaran di kelas. Selain itu aktivitas pengajuan masalah di dalam kelas akan dapat menyebabkan diskusi ide-ide matematika antara siswa satu dengan yang lainnya menjadi lebih kondusif. Temuan penelitian ini serupa dengan temuan yang sifatnya respon kuantitatif oleh Silver dan Cai (1996a) tentang analisis pengajuan masalah matematika yang melibatkan 509 siswa kelas 6 dan kelas 7. Studi ini menemukan bahwa dari 1465 respons yang diajukan oleh responden, terdapat $(70 \%)$ respons berupa masalah matematika, (10\%) pertanyaan non-matematika dan (20\%) pernyataan. Sekitar $90 \%$ soal matematika yang diajukan responden dapat diselesaikan dan sesuai dengan situasi yang diberikan.

Hasil-hasil yang diperoleh dari beberapa temuan ini menunjukan bahwa pembelajaran dengan pendekatan problem posing memberi kesempatan kepada siswa untuk mengembangkan kreativitas siswa melalui pemberian situasi masalah. Dengan kata lain situasi masalah yang menarik, menantang, dan kontekstual dapat menginsprirasi para siswa mengembangkan ideide kreatif baik individual maupun kelompok untuk mengajukan atau membuat masalah matematika dengan tingkat kompleksitas yang beragam. Dari sudut pandang paedagogik matematika ekplorasi melalui pendekatan problem posing dapat meningkatkan kemampuan siswa untuk mengembangkan kemampuan berpikir orsinil, kemampuan berpikir kritis, kemampuan koneksi dan penalaran matematika (mathematics as reasoning) untuk menyelesaikan masalah matematika (mathematics as problem solving) serta kemampuan komunikasi (mathematics as communication) dalam menyampaikan hasil-hasil dari penyelesaian masalah matematika yang siswa ajukan.

Berdasarkan temuan di atas, mengungkapkan bahwa pembelajaran dengan menggunakan pendekatan problem posing efektif dapat meningkatkan hasil belajar matematika siswa serta dapat meningkatkan kemampuan siswa di dalam pemecahan masalah.

\section{Simpulan dan Saran Simpulan}

Dari hasil pengujian hipotesis dan pembahasan hasil penelitian diberikan kesimpulan penelitian sebagai berikut;
Pertama, pembelajaran matematika dengan pendekatan problem posing mampu membuat siswa aktif dan kreatif. Hal ini terlihat dari kemampuan siswa mengembangkan soal matematika sendiri berdasarkan informasi yang diberikan. Siswa mampu mengolah dan mengeksplorasi informasi yang ada dan mengajukan masalah atau soal-soal matematika yang dapat diselesaikan. Melalui pembelajaran dengan pendekatan problem posing juga dapat meningkatkan aktivitas siswa dalam proses pembelajaran, khususnya dalam berinteraksi dan sharing idea dengan siswa lain maupun dengan guru sehingga kegiatan pembelajaran lebih bermakna dan pemahaman siswa terhadap konsep menjadi lebih baik.

Kedua, hasil belajar matematika siswa pada pokok bahasan aritmetika sosial yang diajar menggunakan pendekatan problem posing lebih tinggi dibandingkan dengan hasil belajar siswa yang diajar dengan menggunakan pendekatan konvensional. Hal ini dapat dilihat dari rata-rata hasil belajar matematika siswa yang diberi pendekatan problem posing sebesar 71,20 lebih tinggi daripada rata-rata hasil belajar matematika siswa yang diberi pendekatan konvensional sebesar 61,60 . Dengan demikian pendekatan problem posing berpengaruh secara signifikan terhadap hasil belajar matematika.

\section{Saran}

Berdasarkan kesimpulan di atas, dapat diberikan saran-saran kepada para guru calon guru matematika, dan siswa yaitu sebagai berikut:

Pertama, kepada para guru diharapkan mampu memberikan kesempatan kepada siswa untuk terlibat secara aktif mengajukan masalah matematika, mengemukakan suatu gagasan, dan memecahkan matematika. Kedua, Guru dapat menjadikan pembelajaran dengan pendekatan problem posing ini sebagai salah satu alternatif dalam melaksanakan proses pembelajaran di sekolah. Ketiga, kegiatan pengajuan masalah matematika yang dilakukan oleh siswa akan berkembang dengan baik, jika tugas atau masalah matematika dapat dieksplorasi oleh siswa. Oleh karena itu, guru perlu mengembangkan tugastugas matematika yang kontekstual, menarik, menantang, inspiratif, dan menstimulasi siswa untuk mengajukan masalah matematika dengan 
kompleksitas yang tinggi dan bermutu. Keempat, model pengajuan atau pembentukan soal atau masalah matematika dengan pendekatan problem posing yang diberikan dalam penelitian ini dapat dijadikan sebagai model belajar matematika secara mandiri guna meningkatkan kemampuan pemahaman konsep, penalaran, koneksi, komunikasi dan pemecahan masalah matematika yang merupakan inti dari pembelajaran matematika sebagai suatu proses.

\section{Pustaka Acuan}

Brown, S.I. \& Walter, M.I. 1990. The Art of Problem Posing: Second Edition. New Jersey: Lawrence Erbaum Assosiates.

Gita, Nyoman. 1999. Pengembangan Strategi Pengajuan Masalah Dalam Pembelajaran Matematika Di SMU, Aneka Widya STKIP Singaraja Vol. No. 1 Th. XXXII.

Hudojo, Herman. 1989. Belajar Mengajar Matematika, Jakarta: Depdikbud.

National Council of Teacher of Mathematics. 1989. Curruculum and Evalution Standarts for School Mathematics. Reston Virginia: NCTM.

Nurdin, Mochamad; Mumu; Rustandi, Tantau; Hidayat, Syarief; Jalaludin, Syafrudin. 1998. Pedoman Guru Matematika SLTP Kelas I, Jakarta : Depdikbud.

Ruseffendi, E.T. 1980. Pengajaran Matematika Modern Untuk Orang Tua Murid, Guru dan SPG, Bandung : Tarsito, Cet. ke-1.

Silver and Cai. 1996a. An Analysis of Arithmetic Problem Posing By Middle School Students. Journal for Research in Mathematics Education. Vol. 27.

Silver and Cai., 1996b. Problem Posing Mathematical Problem: An Explorary Study. Journal for Research in Mathematics Education. Vol. 27.

Sudjana, Nana. 1989. Cara Belajar Siswa Aktif (CBSA) Dalam Proses Belajar Mengajar, Bandung: Rosda Karya.

Suharta, I Gusti Putu. 2001. Peningkatan Pemecahan Masalah Matematika Melalui Pengintegrasian Pengajuan Masalah (Problem Posing), Aneka Widya IKIP Singaraja No. 4 th XXXIV.

Suherman, Erman dan Udin S Winataputra. 1992. Strategi Belajar Mengajar Matematika, Jakarta: Depdikbud.

Suherman, Eman,. 2002. Strategi Pembelajaran Matematika Kontemporer, Bandung: UPI.

Sukmadinata, Nana Syaodih. 2003. Landasan Psikologi Proses Pendidikan, Bandung: PT. Remadja Rosdakarya Offset Cet. I.

Syah, Muhibbin. 2004. Psikologi Belajar, Jakarta: PT. Raja Grafindo Persada, 2004, Cet.III. 